\title{
Wood density and wood shrinkage in relation to initial spacing and tree growth in black spruce (Picea mariana)
}

\author{
Shu Yin Zhang ${ }^{1} \mathbb{B}$, Haiqing Ren ${ }^{2}$ and Zehui Jiang ${ }^{1 *}$
}

\begin{abstract}
This study has quantified basic wood density and various types of wood shrinkage in relation to initial spacing (or initial planting density) and tree growth based on a 48-year-old black spruce (Picea mariana) spacing trial in eastern Canada. A total of 139 sample trees were collected from four initial spacings $(3086,2500,2066,1372$ trees/ha) for this study. Analyses of variance (ANOVA) show that initial spacing is the most important parameter affecting wood density significantly, followed by tree diameter at breast height (DBH) class. With increasing spacing, wood density, radial and volumetric shrinkage tend to decrease, whereas longitudinal shrinkage tends to increase gradually. The largest spacing has the lowest wood density, the smallest transverse shrinkage and the largest longitudinal shrinkage. Path analysis indicates that wood density is the most important parameter affecting transverse shrinkage, followed by the distance from the pith. Furthermore, much of the variation of the transverse shrinkage with wood density may be due to the initial spacing and tree DBH class. Path analysis also reveals that longitudinal shrinkage is mainly related to log height and tree DBH class. With increasing log height, longitudinal shrinkage tends to increase, and transverse shrinkage tends to decrease. With increasing DBH class, the trees tend to have an increasing longitudinal shrinkage and a decreasing transverse shrinkage. Overall, this study suggests that a large increase in the initial spacing (e.g., 1372 trees/ha) might lead to a significant reduction in both wood density and transverse shrinkage, and a significant increase in longitudinal shrinkage in black spruce.
\end{abstract}

Keywords: Black spruce, Basic wood density, Wood shrinkage, Initial stand density, Tree growth, Log height, Path analysis

\section{Introduction}

Black spruce (Picea mariana [Mill.] B.S.P.) is the most important reforestation and commercial species in eastern Canada. The black spruce wood is highly valued for both pulpwood and lumber production [1, 2]. Initial spacing has a decisive effect on crown structure, tree growth and stand yield $[3,4]$. For decades, an initial spacing (or initial planting density) of $2 \times 2 \mathrm{~m}$ (2500 trees/ ha) has been adopted for black spruce reforestation in

\footnotetext{
*Correspondence: jiangzh@icbc.ac.cn

${ }^{1}$ International Centre for Bamboo and Rattan, No. 8, Futong Dongdajie, Chaoyang District, Beijing 100102, China

Full list of author information is available at the end of the article
}

eastern Canada [5]. However, larger spacings have been advocated over the years to reduce establishment costs and accelerate diameter growth of individual trees [5]. In fact, initial planting density for black spruce in some regions of eastern Canada has already been reduced to some 2000 trees/ha or even lower. While an increase in initial spacing for black spruce is an effective way to reduce initial establishment costs and to accelerate diameter growth of individual trees, this practice may have negative effects on wood quality attributes for solid products and their product properties [5]. So far, only a few basic wood properties including tracheid length and wood density [6], sapwood and heartwood content [7] and juvenile wood content [8] were evaluated primarily 
based on small clear samples of increment cores in black spruce. Clearly, the forest industry and governments in eastern Canada need a better understanding of the impacts of different initial spacings on the whole value recovery chain from stem and wood quality attributes to product properties and value recovery. Therefore, a multidisciplinary project [9] was undertaken to quantify the impacts of initial stand density along the wood value chain including major wood and product properties in black spruce based on one of the oldest and well-documented initial spacing trials in eastern Canada. As part of this project, this study was intended to quantify the impacts of initial stand density and tree growth on wood density and wood shrinkage, two wood quality attributes of high importance to solid wood products.

The effects of tree growth on wood density in black spruce have been studied extensively and summarized in the book by Zhang and Koubaa [10]. However, the intrinsic effects of various potential variables such as initial spacing and tree growth on wood shrinkage and wood density in black spruce are still poorly understood. It is widely accepted that transverse shrinkage in coniferous species is controlled by an interaction of several variables. The major determinants seem to be the amount of wood substance, the average microfibril angle in the cell wall and the extent of lignification in the cell wall. However, one can easily enlarge this list to include numerous other characteristics such as the lignin content, the amount of extractives, the percentage of ray cells, and the value of the fiber saturation point [11-13]. Panshin and De Zeeuw [14] stated that differential shrinkage could not be simply explained, and each theory that was advanced offered only a partial explanation of the observed phenomena. On the other hand, longitudinal shrinkage is usually believed to be closely correlated with microfibril angle in the cell wall $[15,16]$. Therefore, while this study was intended to quantify the impact of initial spacing on wood density and wood shrinkage, great efforts were made to examine the intrinsic relationship of wood density and wood shrinkage with stand density and tree growth in black spruce.

\section{Materials and methods Materials}

This study was based on a 48-year-old initial spacing trial established by the Ontario Ministry of Natural Resources. One site located in Stanley $\left(49^{\circ} 22^{\prime} \mathrm{N}, 89^{\circ} 23^{\prime}\right.$ W), $10 \mathrm{~km}$ north of Thunder Bay, provided the materials for this study. The trial area is classified by Rowe [17] as Superior of the Boreal Forest Region. Soil texture is fine sandy loams over sandy clay loam [5]. The estimated site index (mean dominant height at age 50) for black spruce is $18 \mathrm{~m}$ [18]. The seeds were collected from natural stands in Northern Ontario. Since the establishment of the trial, no management other than protection had been applied to alter growth and development, and all the plots in the trial had been measured by the Ontario Ministry of Natural Resources on a regular basis to study the growth and development of the black spruce plots. Based on the historic measurements and stand dynamics analysis of the plots in the trial, those plots falling into the four categories of initial density (viz., 1372, 2066, 2500, 3086 trees/ ha) were identified by the OMNR for this study. All trees in the plots of the four densities were marked and measured for diameter at breast height (DBH). The measurements provided the DBH distribution for each of the four densities. Sample trees from each density were selected based on the DBH class distribution. From each stand density, six trees per merchantable 2-cm DBH class (e.g., $10,12,14, \ldots)$ were selected randomly. There were a few exceptions where insufficient number of trees were available from either the smallest or the largest DBH class. From the initial density of 1372 trees/ha, 30 sample trees were selected to cover 6 DBH classes (viz., 16-24 cm); 33 trees were selected from the density of 2066 trees/ha to cover 7 DBH classes (viz., 10-22 cm); 40 trees from the density of 2500 trees/ha were selected to cover 7 DBH classes (viz. 10-22 cm); and 36 trees from the density of 3086 trees/ha were selected to cover 6 DBH classes (viz. 10-20 cm). In total, 139 trees were collected for this study. More details on the trial and sample trees are available in the report [9].

\section{Methods}

Each sample tree was bucked into 2.44-m (or 8-ft) long logs. From the top of each log, a 3-cm-thick disk was removed for the evaluation of basic wood characteristics. The log position in the tree (e.g., from butt log to top $\log$ ) was identified by different letters (e.g., A, B, C...). Log diameter at each end and the average bark thickness was measured, and log defect (e.g., sweep, crook, rot) was recorded for each log. To facilitate the primary $\log$ breakdown and to identify the origin of each piece of lumber, the ends of the logs from each of the four densities were painted with different colors. Special arrangements were made with a cooperating sawmill to reduce processing speed in order to mark the origin of each piece of lumber produced. All the logs for this study were processed in the same manner from debarking to sawing. Logs from each of the four densities were processed separately to collect chip samples. After debarking, logs were sorted into 4-size groups (viz., 3, 4, 6, 8 in) before they were sawn into 5 - $\mathrm{cm}$-thick lumber. The tree number and sawlog position in the tree were noted for each piece of lumber. 
All pieces of lumber samples were brought to the FPInnovations-Forintek laboratory in Quebec City where moisture content was measured for each piece of lumber at the green condition. The lumber pieces were then stored into a conditioning chamber until they reached approximately $12 \%$ moisture content. Following the bending tests [19], two $15-\mathrm{cm}$ long (longitudinal) blocks of wood specimen were removed from the two ends of each piece of tested lumber. The number of the block specimens from each sample tree varies, depending upon the tree size. The cross-section dimension of the specimens is roughly $5 \times 7.5 \mathrm{~cm}, 5 \times 10 \mathrm{~cm}$ and $5 \times 15 \mathrm{~cm}$, depending upon the lumber size. Based on the two block specimens from each piece of lumber, mean averages of basic wood density and wood shrinkage were determined for each piece of lumber. Then, mean averages of basic wood density and wood shrinkage were calculated for each sample tree, each DBH class and each stand, respectively, for statistical analysis. In addition, cambial age, ring width, the distance (of the lumber) to the pith were recorded for each specimen.

The wood shrinkage specimens were submerged in water until they reached approximately $100 \%$ moisture content. The cross-section dimension and length of each specimen were measured to $0.001 \mathrm{~mm}$ at the green condition using a digital micrometer. The measured positions were also marked for each specimen. The green specimens were open-piled and allowed for air-drying at the room condition for a few days. After the air-drying, the specimens were oven-dried at $103 \pm 2{ }^{\circ} \mathrm{C}$ until a constant mass was reached. Then, the oven-dry weight was determined and the cross-section dimension was measured again at the same positions. The wood shrinkage values in this study were calculated based on the dimensional changes from the green to the oven-dry conditions. Basic wood density was determined based on the oven-dry weight and green volume.

\section{Path analysis}

Stand density, tree growth (e.g., DBH) and wood characteristics (e.g., wood density, juvenile wood content), to a varying degree, affect different types of wood shrinkage. However, it is difficult to quantify and compare their intrinsic effects or relative importance to wood shrinkage. The partial regression analysis is one of the most important techniques to quantify the influence of $i$ cause factor $X_{i}$ upon $Y$. However, partial regression coefficients $B_{1}, B_{2} \ldots B_{\mathrm{n}}$ are related to the unit of the factors, and thus they cannot be used for the comparison of the influences of $X_{1}, X_{2}, \ldots X_{\mathrm{n}}$ upon $Y$. By eliminating the influence of the unit, path analysis serves as a useful tool to compare the relative importance of basic wood anatomical variables to wood properties [20]. In this study, path analysis has been employed to quantify and compare the impacts of various stand and tree variables on different types of wood shrinkage and wood density. The parameters needed to calculate various direct and indirect path coefficients were obtained using Statistical Analysis System (SAS) package. More details on path analysis are provided by Zhang and Zhong [20].

\section{Results and discussion \\ Wood density in relation to initial stand density and tree growth}

As shown in Table 1, with increasing spacing, average wood density tends to decrease from 375 to $365 \mathrm{~kg} /$ $\mathrm{m}^{3}$. As a matter of fact, the three higher stand densities have a comparable wood density, only the lowest stand density (1372 trees/ha) has an appreciably lower wood density $\left(365 \mathrm{~kg} / \mathrm{m}^{3}\right)$. This implies that a too large spacing (e.g., 1372 trees/ha) may lead to a significant decrease in wood density. The analysis of variance (ANOVA) results (Table 2) show that initial spacing has a significant effect on basic wood density at the 0.01 level.

As shown in Fig. 1, with increasing DBH class from 10 to $24 \mathrm{~cm}$, basic wood density decreases steadily, and it applies to the four stand densities. This suggests that

Table 1 Wood shrinkage and wood density in relation to initial stand density

\begin{tabular}{lllllll}
\hline Stand density (trees/ha) & \multicolumn{2}{l}{$\begin{array}{l}\text { Number of } \\
\text { specimens }\end{array}$} & \multicolumn{2}{l}{ Wood shrinkage (\%) } & WD $\left(\mathrm{kg} / \mathrm{m}^{3}\right)$ \\
\cline { 3 - 5 } & & RS & TS & LS & VS \\
\hline 1372 & 200 & $3.53(0.70)$ & $5.84(1.02)$ & $0.29(0.17)$ & $9.44(1.35)$ & $365(63)$ \\
2066 & 153 & $3.76(0.63)$ & $5.92(0.98)$ & $0.25(0.11)$ & $9.71(1.25)$ & $372(68)$ \\
2500 & 179 & $3.81(0.60)$ & $5.82(0.96)$ & $0.25(0.16)$ & $9.70(1.38)$ & $375(69)$ \\
3086 & 158 & $3.82(0.73)$ & $6.04(0.97)$ & $0.23(0.11)$ & $9.85(1.38)$ & $375(71)$ \\
Combined & 690 & $3.72(0.68)$ & $5.90(0.93)$ & $0.26(0.14)$ & $9.66(1.34)$ & $372(67)$ \\
\hline
\end{tabular}

$R S$ radial shrinkage, TS tangential shrinkage, LS longitudinal shrinkage, VS volumetric shrinkage, WD basic wood density

Values in the parentheses are the standard deviations 
Table 2 ANOVA analysis of the effects of initial stand density, DBH class and log height on wood shrinkage and wood density

\begin{tabular}{llll}
\hline \multirow{2}{*}{$\begin{array}{l}\text { Wood quality } \\
\text { attributes }\end{array}$} & \multicolumn{3}{l}{$P$-value and significant level } \\
\cline { 2 - 4 } & Stand density & DBH class & Log height \\
\hline RS & $0.000^{* *}$ & $0.000^{* *}$ & $0.000^{* *}$ \\
TS & 0.175 & 0.051 & $0.030^{*}$ \\
LS & $0.002^{* *}$ & $0.006^{* *}$ & $0.000^{* *}$ \\
VS & $0.018^{*}$ & $0.002^{* *}$ & $0.000^{* *}$ \\
WD & $0.010^{* *}$ & $0.003^{* *}$ & $0.000^{* *}$ \\
\hline
\end{tabular}

$R S$ radial shrinkage, $T S$ tangential shrinkage, $L S$ longitudinal shrinkage, VS volumetric shrinkage, $W D$ basic wood density

** Significant at the 0.01 level; *significant at the 0.05 level

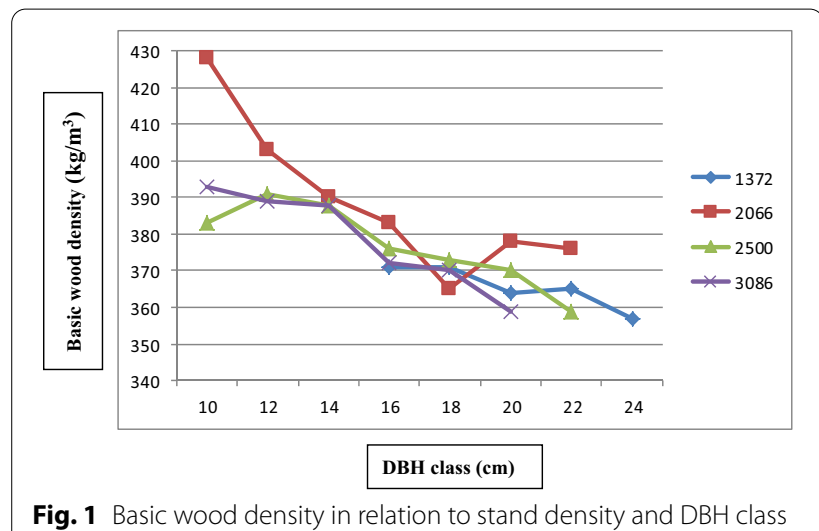

faster-growing trees tend to have a lower wood density regardless of stand density. The ANOVA analysis (Table 2) shows that DBH class has a significant effect on basic wood density at the 0.01 significant level. A higher wood density associated with smaller DBH classes, to some extent, may explain why lumber from smaller DBH classes have significantly higher lumber bending modulus of elasticity (MOE) and modulus of rupture (MOR), as reported previously [19].

As shown in Fig. 2, with increasing log height from the butt $\log$ ( 0 to 8 feet high or $0-2.44 \mathrm{~m}$ high) to the top log (40 feet to 48 feet high or $12.2 \mathrm{~m}$ to $14.64 \mathrm{~m}$ high), the log wood density shows a steady and consistent increase, and this trend applies to the four stand densities. This suggests that regardless of stand density, the butt log in the black spruce has the lowest wood density, whereas the top log has the highest wood density. The ANOVA results (Table 2) show that log height also has a significant effect on wood density at the 0.01 significant level. If the black spruce logs are used to manufacture machine stress-rated (MSR) lumber, this finding suggests that it might be feasible to segregate the logs by log height (position) and tree DBH class as these two attributes, to a large extent, determine wood density and thus mechanical properties.

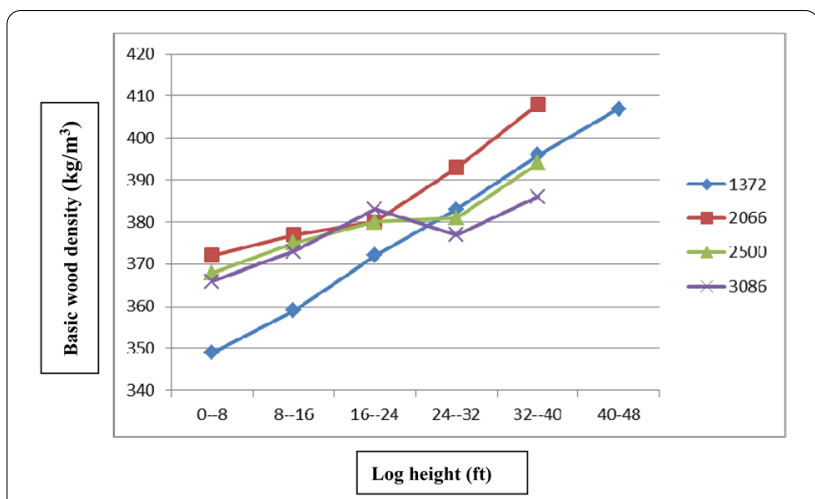

Fig. 2 Basic wood density in relation to stand density and log height

Table 3 Direct and indirect path coefficients of various variables affecting basic wood density $\left(Y_{1}\right)$

\begin{tabular}{lrrrrr}
\hline & $X_{1} \rightarrow Y_{1}$ & \multicolumn{1}{c}{$X_{2} \rightarrow Y_{1}$} & \multicolumn{1}{c}{$X_{3} \rightarrow Y_{1}$} & \multicolumn{1}{c}{$X_{4} \rightarrow Y_{1}$} & \multicolumn{1}{c}{$X_{5} \rightarrow Y_{1}$} \\
\hline$X_{1} \rightarrow$ & 0.1726 & 0.3029 & -0.1373 & 0.3804 & 0.0356 \\
$X_{2} \rightarrow$ & 0.0432 & $\mathbf{1 . 2 1 1 0}$ & -0.6651 & 0.1206 & -0.0372 \\
$X_{3} \rightarrow$ & -0.0163 & -0.5556 & $\mathbf{1 . 4 4 9 8}$ & -0.1020 & 0.0173 \\
$X_{4} \rightarrow$ & 0.0825 & 0.1836 & -0.1859 & $\mathbf{0 . 7 9 5 7}$ & 0.0240 \\
$X_{5} \rightarrow$ & -0.0420 & 0.3078 & -0.1709 & -0.1306 & -0.1464 \\
\hline
\end{tabular}

$X_{1}=\log$ height,$X_{2}=\mathrm{DBH}$ class, $X_{3}=$ stand density $X_{4}=$ ring width, $X_{5}=$ distance from the pith, $X_{6}=$ basic wood density

Major direct path coefficients are highlighted in bold

To further quantify and compare the intrinsic effects of various variables on wood density, path analysis has been performed to identify those variables that show major direct effect as indicated by a large direct path coefficient. As shown in Table 3, stand density has the highest direct path coefficient (1.4498), followed by DBH class (1.2110) and ring width (0.7957), whereas the other variables have a small direct path coefficient. This indicates that stand density is the most important variable affecting wood density significantly, followed by DBH class or radial growth. The path analysis also shows that stand density has a large indirect coefficient through DBH class $(-0.5556)$. This implies that stand density also has a considerable indirect effect on wood density through tree DBH class. Similarly, DBH class also has a considerable indirect effect on wood density through stand density, as $\mathrm{DBH}$ has a large indirect coefficient through stand density ( -0.6651$)$. This, to a large extent, reflects the close relationship between stand density and tree DBH growth in black spruce [9]. Overall, the path analysis confirms that initial spacing has the most important effect on wood density, followed by tree DBH class. Although Fig. 2 shows a close relationship of wood density with log position, path analysis reveals that log height has a small 
direct path coefficient (0.1726); instead it has a large indirect coefficient through ring width (0.3804) and DBH class (0.3029). This implies that the strong correlation of wood density with log height is largely due to ring width and tree DBH class. In other words, the variation of wood density with log height in the tree may be largely due to the difference in ring width or diameter growth among the logs in the tree. Koubaa et al. [21] and Alteyrac et al. [22] studied the radial variation in wood density and ring width with cambial age. Both ring width and ring wood density in black spruce are high nearby the pith, and then decreases considerably with increasing cambial age until up to 10 years old. This implies that the juvenile wood zone in this species has a considerably higher ring width and wood density than the mature wood. Thus, it is understandable that the top log in black spruce has a significantly higher wood density as it has a higher juvenile wood content.

A preliminary study by Yang and Hazenberg [6] examined the effects of initial spacing on wood density. The effect of growth rate on wood density in black spruce was summarized by Zhang and Koubaa [10]. This study has compared the intrinsic effects of both initial spacing and tree growth on wood density. Overall, initial spacing has the most important and significant effect on wood density of black spruce trees, the largest spacing has a significantly lower wood density. Tree DBH also has a considerable effect on wood density, whereas log height does not show a significant effect on wood density despite large differences among the logs of different heights in the tree. Besides wood density, stem characters (e.g., knottiness, clear log length, taper) and other wood quality attributes (e.g., wood shrinkage, mechanical properties) are also important when the wood is used for solid products. A study [9] found that larger spacings also led to a significantly larger crown size, knot diameter and stem taper. Therefore, a significant reduction in stem and

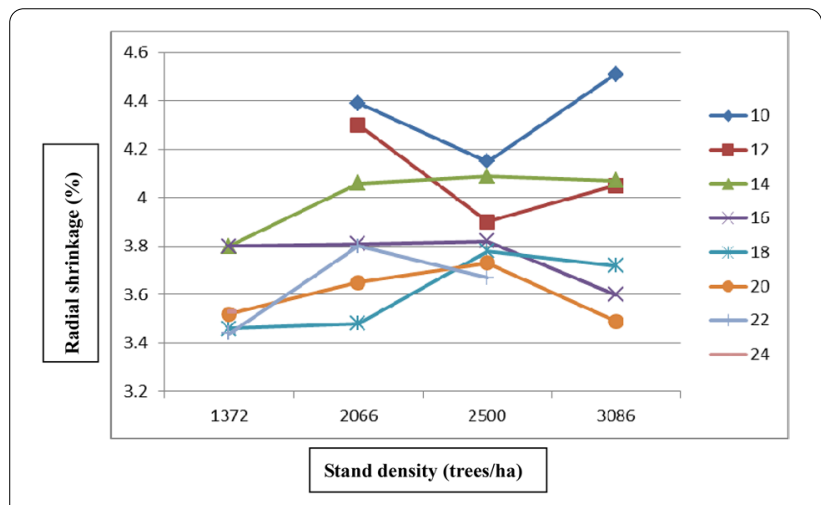

Fig. 3 Radial shrinkage in relation to stand density and DBH class wood quality attributes is expected in black spruce if the initial spacing increases excessively (e.g., 1372 trees/ha).

\section{Wood shrinkages in relation to initial stand density and tree growth Wood shrinkage in relation to stand density}

As shown in Table 1 and Figs. 3, 4, 5 and 6, with increasing initial spacing, longitudinal shrinkage tends to increase from 0.23 to $0.29 \%$, whereas radial and volumetric shrinkage tends to decrease gradually. Tangential shrinkage does not show a consistent pattern of variation with stand density. The ANOVA analysis (Table 2) confirms that statistically the four stand densities have a significant difference in longitudinal and transverse shrinkage except for tangential shrinkage. The largest spacing (1372 trees/ha) has the largest longitudinal shrinkage and the smallest transverse shrinkage.

\section{Wood shrinkage in relation to tree $D B H$}

Figures 3, 4, 5 and 6 present different types of wood shrinkage in relation to tree DBH class in the four stand densities. With increasing DBH from 10 to $24 \mathrm{~cm}$, radial

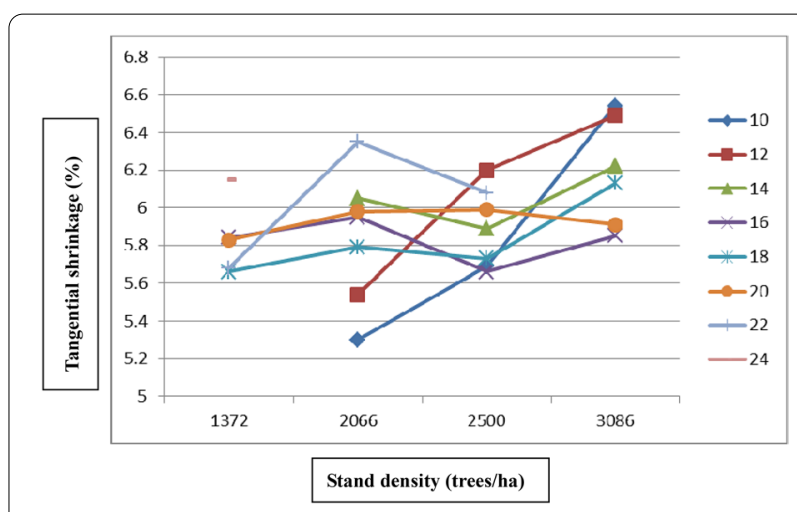

Fig. 4 Tangential shrinkage in relation to stand density and DBH class

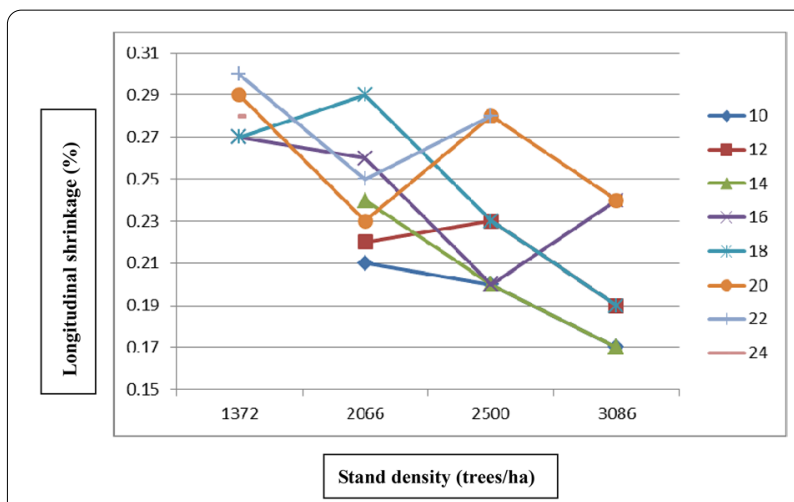

Fig. 5 Longitudinal shrinkage in relation to stand density and DBH class 


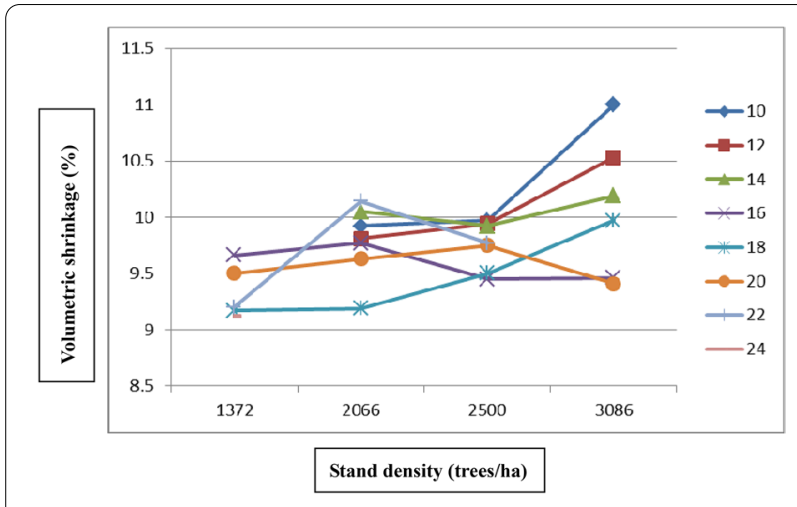

Fig. 6 Volumetric shrinkage in relation to stand density and $\mathrm{DBH}$ class

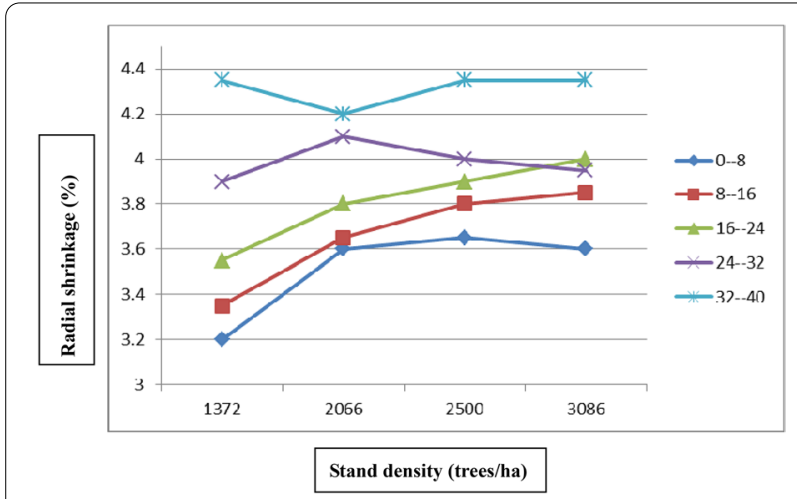

Fig. 7 Radial shrinkage in relation to log height and stand density

and volumetric shrinkage tend to decrease, whereas longitudinal shrinkage generally tends to increase. However, tangential shrinkage does not appear to show a consistent pattern of variation with DBH class. The ANOVA analysis (Table 2) indicates that the DBH class also has a significant effect on various types of wood shrinkage except for tangential shrinkage.

\section{Wood shrinkage in relation to log height in the tree}

Figures 7, 8, 9 and 10 show various types of wood shrinkage in relation to log height in the four stand densities. With increasing log height from the butt log (0-8 feet high or 0 to $2.44 \mathrm{~m}$ high) to the top $\log$ (32 feet to 40 feet high or $9.76 \mathrm{~m}$ to $12.2 \mathrm{~m}$ high), radial shrinkage shows an appreciable increase, and it applies to the four stand densities. The same trend, to some extent, applies to volumetric and tangential shrinkage in most stand densities. However, longitudinal shrinkage shows an opposite pattern of variation with log height. As shown in Fig. 9, with increasing log height, longitudinal shrinkage tends to decrease appreciably in most stand densities. The

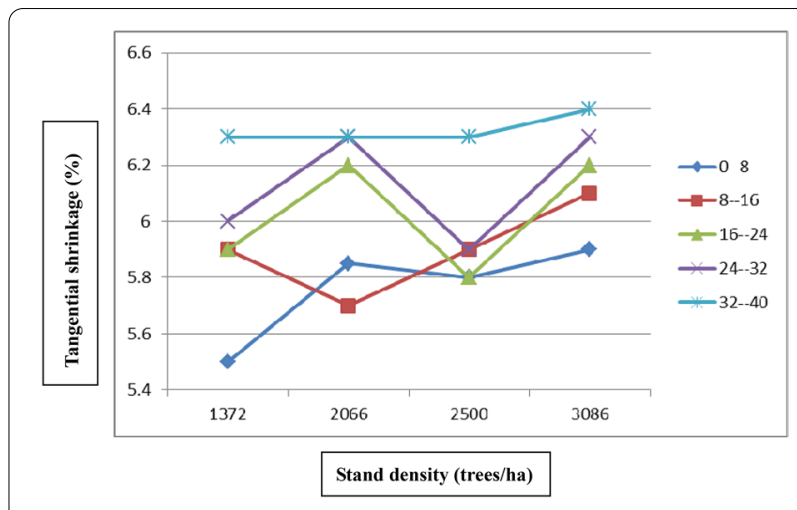

Fig. 8 Tangential shrinkage in relation to log height and stand density

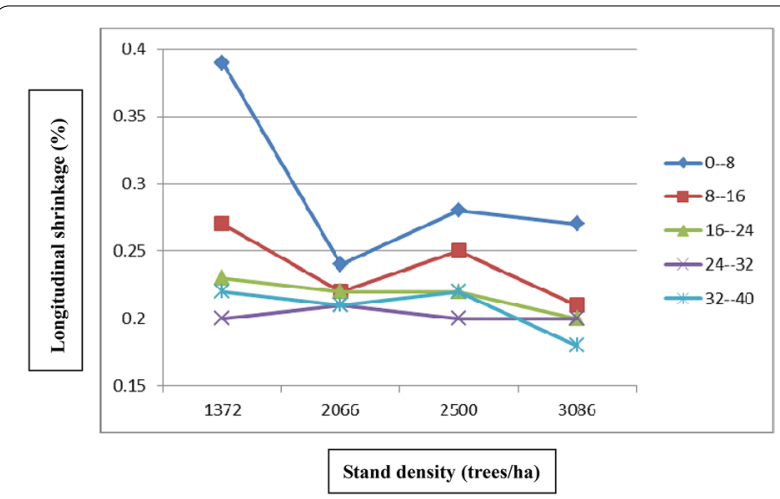

Fig. 9 Longitudinal shrinkage in relation to log height and stand density

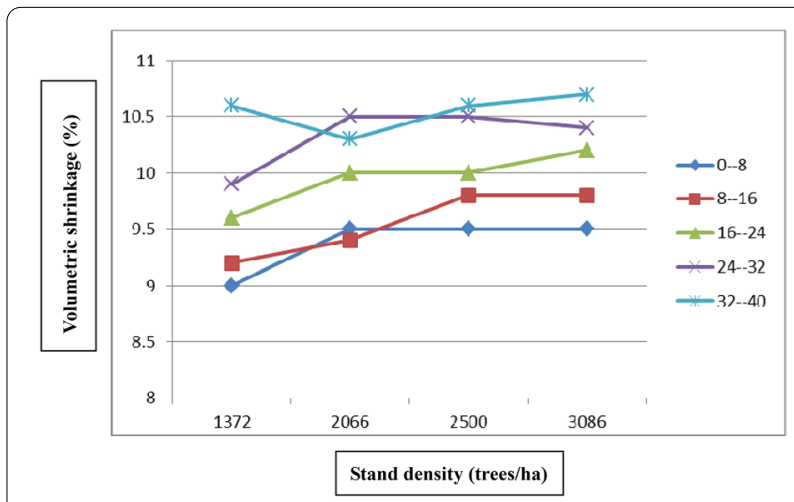

Fig. 10 Volumetric shrinkage in relation to log height and stand density

ANOVA analysis (Table 2) shows that log height also has a significant effect on longitudinal and transverse shrinkage. Overall, the top log in black spruce has the 
largest transverse shrinkage and the smallest longitudinal shrinkage, whereas the butt log has the smallest transverse shrinkage and the largest longitudinal shrinkage.

\section{Path analysis of wood shrinkage in relation with stand density and tree growth}

The above analyses indicate that stand density, tree growth, wood density and wood shrinkage appear to be inter-correlated with one another. Thus, path analysis has been performed to examine the intrinsic relationship of different types of wood shrinkage with stand density, tree growth and wood attributes including wood density, the distance from the pith and ring width, as shown in Tables 4, 5, 6 and 7.
With respect to radial shrinkage (Table 4), wood density among the six variables has the largest direct path coefficient $(0.3751)$, followed by the distance from the pith (with a direct path coefficient of -0.2430 ), whereas stand density has an almost neglectable direct path coefficient (with a very small direct path coefficient of 0.0709). This indicates that wood density is the most important parameter affecting radial shrinkage, followed by distance from the pith, whereas stand density does not have a large direct effect on radial shrinkage. This result is obviously different from the previous analysis which examined the relationship of radial shrinkage with only stand density without considering other variables. With respect to tangential shrinkage (Table 5), wood density has the highest direct path coefficient $(0.2991)$ as well,

Table 4 Direct and indirect path coefficients of various variables affecting radial shrinkage $\left(Y_{2}\right)$

\begin{tabular}{|c|c|c|c|c|c|c|}
\hline & $X_{1} \rightarrow Y_{2}$ & $X_{2} \rightarrow Y_{2}$ & $X_{3} \rightarrow Y_{2}$ & $X_{4} \rightarrow Y_{2}$ & $X_{5} \rightarrow Y_{2}$ & $X_{6} \rightarrow Y_{2}$ \\
\hline$x_{1} \rightarrow$ & 0.1411 & -0.0130 & -0.0067 & -0.0170 & 0.0591 & 0.1422 \\
\hline$x_{2} \rightarrow$ & 0.0353 & -0.0522 & -0.0325 & -0.0054 & -0.0618 & -0.1345 \\
\hline$x_{3} \rightarrow$ & -0.0134 & 0.0239 & 0.0709 & 0.0045 & 0.0286 & 0.0445 \\
\hline$x_{4} \rightarrow$ & 0.0675 & -0.0079 & -0.0091 & -0.0355 & 0.0399 & 0.0598 \\
\hline$x_{5} \rightarrow$ & -0.0343 & -0.0133 & -0.0084 & 0.0058 & -0.2430 & -0.1257 \\
\hline$x_{6} \rightarrow$ & 0.0535 & 0.0187 & 0.0084 & -0.0057 & 0.0815 & 0.3751 \\
\hline
\end{tabular}

$X_{1}=\log$ height, $X_{2}=\mathrm{DBH}$ class, $X_{3}=$ stand density $X_{4}=$ ring width, $X_{5}=$ distance from the pith, $X_{6}=$ basic wood density

Major direct path coefficients are highlighted in bold

Table 5 Direct and indirect path coefficients of various variables affecting tangential shrinkage $\left(Y_{3}\right)$

\begin{tabular}{|c|c|c|c|c|c|c|}
\hline & $X_{1} \rightarrow Y_{3}$ & $X_{2} \rightarrow Y_{3}$ & $X_{3} \rightarrow Y_{3}$ & $X_{4} \rightarrow Y_{3}$ & $X_{5} \rightarrow Y_{3}$ & $X_{6} \rightarrow Y_{3}$ \\
\hline$x_{1} \rightarrow$ & -0.0757 & 0.0540 & -0.0121 & 0.0284 & 0.0312 & 0.1134 \\
\hline$x_{2} \rightarrow$ & -0.0189 & 0.2161 & -0.0586 & 0.0090 & -0.0326 & -0.1073 \\
\hline$x_{3} \rightarrow$ & 0.0072 & -0.0991 & 0.1277 & -0.0076 & 0.0151 & 0.0355 \\
\hline$x_{4} \rightarrow$ & -0.0362 & 0.0328 & -0.0164 & 0.0593 & 0.0211 & 0.0477 \\
\hline$x_{5} \rightarrow$ & 0.0184 & 0.0549 & -0.0151 & -0.0097 & -0.1283 & -0.1003 \\
\hline$x_{6} \rightarrow$ & -0.0287 & -0.0775 & 0.0151 & 0.0095 & 0.0430 & 0.2991 \\
\hline
\end{tabular}

$X_{1}=\log$ height, $X_{2}=\mathrm{DBH}$ class, $X_{3}=$ stand density $X_{4}=$ ring width, $X_{5}=$ distance from the pith, $X_{6}=$ basic wood density

Major direct path coefficients are highlighted in bold

Table 6 Direct and indirect path coefficients of various variables affecting longitudinal shrinkage $\left(Y_{4}\right)$

\begin{tabular}{|c|c|c|c|c|c|c|}
\hline & $X_{1} \rightarrow Y_{4}$ & $X_{2} \rightarrow Y_{4}$ & $X_{3} \rightarrow Y_{4}$ & $X_{4} \rightarrow Y_{4}$ & $X_{5} \rightarrow Y_{4}$ & $X_{6} \rightarrow Y_{4}$ \\
\hline$x_{1} \rightarrow$ & -0.3039 & 0.0540 & 0.0062 & 0.0111 & 0.0085 & 0.0349 \\
\hline$x_{2} \rightarrow$ & -0.0760 & 0.2159 & 0.0299 & 0.0035 & -0.0089 & -0.0330 \\
\hline$x_{3} \rightarrow$ & 0.0288 & -0.0991 & -0.0652 & -0.0030 & 0.0041 & 0.0109 \\
\hline$X_{4} \rightarrow$ & -0.1453 & 0.0327 & 0.0084 & 0.0233 & 0.0057 & 0.0147 \\
\hline$x_{5} \rightarrow$ & 0.0739 & 0.0549 & 0.0077 & -0.0038 & -0.0350 & -0.0309 \\
\hline$x_{6} \rightarrow$ & -0.1152 & -0.0774 & -0.0077 & 0.0037 & 0.0117 & 0.0921 \\
\hline
\end{tabular}

$X_{1}=\log$ height, $X_{2}=\mathrm{DBH}$ class, $X_{3}=$ stand density $X_{4}=$ ring width, $X_{5}=$ distance from the pith, $X_{6}=$ basic wood density

Major direct path coefficients are highlighted in bold 
Table 7 Direct and indirect path coefficients of various variables affecting volumetric shrinkage $\left(Y_{5}\right)$

\begin{tabular}{|c|c|c|c|c|c|c|}
\hline & $X_{1} \rightarrow Y_{5}$ & $X_{2} \rightarrow Y_{5}$ & $X_{3} \rightarrow Y_{5}$ & $X_{4} \rightarrow Y_{5}$ & $X_{5} \rightarrow Y_{5}$ & $X_{6} \rightarrow Y_{5}$ \\
\hline$x_{1} \rightarrow$ & -0.0212 & 0.0397 & -0.0116 & 0.0140 & 0.0513 & 0.1566 \\
\hline$x_{2} \rightarrow$ & -0.0053 & 0.1586 & -0.0562 & 0.0045 & -0.0537 & -0.1482 \\
\hline$x_{3} \rightarrow$ & 0.0020 & -0.0728 & 0.1225 & -0.0038 & 0.0249 & 0.0490 \\
\hline$x_{4} \rightarrow$ & -0.0102 & 0.0240 & -0.0157 & 0.0294 & 0.0347 & 0.0659 \\
\hline$x_{5} \rightarrow$ & 0.0052 & 0.0403 & -0.0144 & -0.0048 & -0.2112 & -0.1385 \\
\hline$x_{6} \rightarrow$ & -0.0081 & -0.0569 & 0.0145 & 0.0047 & 0.0708 & 0.4132 \\
\hline
\end{tabular}

$X_{1}=\log$ height, $X_{2}=$ DBH class, $X_{3}=$ stand density $X_{4}=$ ring width, $X_{5}=$ distance from the pith, $X_{6}=$ basic wood density

Major direct path coefficients are highlighted in bold

followed by tree DBH class $(0.2161)$, the distance from the pith $(-0.1283)$ and stand density $(0.1277)$. This indicates that wood density still has the largest direct effect on tangential shrinkage, followed by tree DBH class and the distance from the pith, and initial spacing has less direct effect on tangential shrinkage. Unlike radial and tangential shrinkage, path analysis (Table 6) shows that $\log$ position has the largest effect on longitudinal shrinkage $(-0.3039)$, followed by tree DBH class $(0.2159)$. Neither stand density nor wood density has an appreciable direct effect on longitudinal shrinkage, as they have an almost neglectable direct path coefficient $(-0.06542$ and 0.0921 , respectively). Like radial shrinkage, volumetric shrinkage is the most affected by wood density (0.4132) and the distance from the pith $(-0.2112)$, whereas tree DBH class $(0.1586)$ and stand density $(0.1225)$ have less direct effect on volumetric shrinkage.

Both ANOVA and path analysis show that stand density has a significant effect on wood density which in turn has the most important effect on wood shrinkage. However, path analysis reveals that stand density does not have a large direct effect on wood shrinkage in black spruce. When wood density is excluded as a variable from the path analysis, stand density does show a large direct effect on wood shrinkage as indicated by direct path coefficient. This implies that the relationship of wood shrinkage with stand density might be largely due to the differences in wood density among the four stand densities, as wood density is closely related to stand density. In other words, the effect of stand density on wood shrinkage is largely due to its effect on wood density which in turn affects wood shrinkage significantly.

Although Figs. 3, 4, 5, 6 and 7 and Table 2 show a close correlation of most types of wood shrinkage (except for tangential shrinkage) with tree DBH class, the path analysis indicates that tree DBH class has a major effect on longitudinal shrinkage, whereas radial shrinkage is hardly affected by DBH class. As both ANOVA and path analysis show that tree DBH class has a significant effect on wood density which in turn affects wood shrinkage significantly. Therefore, it is most likely that part of the variation of wood shrinkage with tree DBH class might be due to the differences of tree DBH classes in wood density which has a significant effect on wood shrinkage. Koshy and Lester [23] found that correlations between wood shrinkage and tree growth in Douglas fir were minimal. In addition, several studies [24, 25] reported that wood shrinkage was less correlated with ring width or growth rate than with cambial age. More research is needed to examine wood shrinkage in relation to cambial age and juvenile wood content in black spruce.

Overall, path analysis reveals that wood density is the most important parameter affecting transverse shrinkage, followed by the distance from the pith, whereas stand density and tree growth have rather limited direct effects on transverse shrinkage. However, longitudinal shrinkage is mainly related to log height and tree DBH class, whereas neither stand density nor wood density has appreciable direct effect on longitudinal shrinkage. As wood density serves as an index of the cell wall substance of wood, it is understandable that transverse shrinkage such as volumetric shrinkage is closely related to wood density [14]. However, several studies [13, 24, 25 ] reported that wood shrinkage was only moderately or poorly correlated with wood density. In addition, the close relationship of wood shrinkage with juvenile wood content is also expected, as juvenile wood usually has a larger microfibril angle in the cell wall, and thus larger wood shrinkage and less dimensional stability than the mature wood $[15,16,26]$.

The path analysis reveals that neither stand density nor tree DBH class has a large direct effect on longitudinal shrinkage. Instead, log height is the most important parameter affecting longitudinal shrinkage. As longitudinal shrinkage is usually believed to be closely correlated with microfibril angle $[15,20]$, it is not difficult to understand the relationship of longitudinal shrinkage with log height, as juvenile wood content an microfibril angle vary considerably with log height [22]. Several studies $[3,12,26]$ also reported the 
height effect on wood shrinkage. Koshy and Lester [23] detected a negative correlation of longitudinal shrinkage with tree height in Douglas fir. Cown and $\mathrm{McCo}-$ nchie [27] found that differential shrinkage in radiata pine was also dependent on the log height in the tree. A better understanding of the anatomical and ultrastructural differences among the logs of different heights in the tree might shield the light on the variation of longitudinal shrinkage with log height in black spruce.

\section{Conclusions}

Based on the above analyses, the following conclusions can be drawn:

1. Initial spacing has the most important and significant effect on wood density. With increasing initial spacing, wood density tends to decrease, the lowest stand density (1372 trees/ha) has a significantly lower wood density than the three higher stand densities.

2. Tree DBH class also shows a considerable effect on wood density, but the effect is less significant than initial spacing which affects tree DBH growth significantly.

3. The wood density of logs shows a steady and consistent increase with increasing log height. However, the path analysis reveals that the variation of wood density with log height might be largely due to the difference in the ring width or growth rate among the logs of different heights in the tree.

4. With increasing initial spacing, longitudinal shrinkage tends to increase gradually, whereas radial and volumetric shrinkage appears to decrease gradually. Overall, the largest initial spacing (1372 trees/ha) has the largest longitudinal shrinkage and the smallest transverse shrinkage.

5. With increasing tree DBH class, the trees tend to have an increasing longitudinal shrinkage and a decreasing transverse shrinkage.

6. With increasing log height, longitudinal shrinkage tends to decrease and transverse shrinkage tends to increase. The butt logs have the largest longitudinal shrinkage and the smallest transverse shrinkage.

7. Path analysis reveals that wood density is the most important parameter affecting transverse shrinkage, followed by the distance from the pith. Whereas initial spacing and tree DBH class have less direct effect on transverse shrinkage. On the other hand, longitudinal shrinkage in black spruce is mainly related to log height and tree DBH class.

\section{Abbreviations}

DBH: Diameter at breast height; WD: Basic wood density; RS: Radial shrinkage; TS: Tangential shrinkage; LS: Longitudinal shrinkage; VS: Volumetric shrinkage; MOE: Modulus of elasticity; MOR: Modulus of rupture; MSR lumber: Machine stress-rated lumber; ANOVA: Analysis of variance.

\section{Acknowledgements}

This multidisciplinary project was funded by the Canadian Forest Service in collaboration with the Ontario Ministry of Natural Resources. The support by the Fundamental Research Funds of the International Center for Bamboo and Rattan (ICBR Grant No. 1630219001) is also acknowledged with thanks. We would like to thank Mr. Colin Bowling and Mr. Bill Towill of the Ontario Ministry of Natural Resources for the historic measurement data and their assistance in the selection of the plots for this study. We also would like to thank Mr. Gilles Chauret, Mr. Luc Bébard and Mr. Alan Kostiuk of FPInnovations for their participation in the field work.

\section{Authors' contributions}

As the project leader, the first author initiated the project, and undertook the project design and sampling, statistical analyses and interpretations, and drafting of the manuscript. The second author as postdoctoral fellow undertook the laboratory testing, data compilation and basic analyses. The third author supervised the postdoctoral fellow and supported the study. All authors read and approved the final manuscript.

\section{Funding}

This research was funded by the Canadian Forest Service in collaboration with the Ontario Ministry of Natural Resources. The support by the Fundamental Research Funds of the International Center for Bamboo and Rattan (ICBR Grant No. 1630219001) is also acknowledged with thanks.

\section{Availability of data and materials}

All the data used in this article are from a project undertaken at FPInnovations in Quebec City Laboratory under the project entitled "Impacts of initial spacing on wood characteristics, product properties and product recovery in black spruce". The complete datasets should be available with the consent of FPInnovations.

\section{Declarations}

\section{Competing interests}

The authors declare no conflict of interests.

\section{Author details}

${ }^{1}$ International Centre for Bamboo and Rattan, No. 8, Futong Dongdajie, Chaoyang District, Beijing 100102, China. ${ }^{2}$ Chinese Academy of Forestry, Beijing 100091, China.

Received: 30 October 2020 Accepted: 1 April 2021

Published online: 13 April 2021

\section{References}

1. Canadian Council of Forest Ministers (1996) Forest regeneration in Canada 1975-1992. Ottawa

2. Mullins EJ, McKnight TS (1981) Canadian woods. Univ. Toronto Press, Toronto

3. Daniel TW, Helms JA, Baker FS (1979) Principles of silviculture. McGrawHill Book Company, New York

4. Evert F (1971) Spacing studies: a review. Information report FMR-X-37, Can For Serv, Sault Ste-Marie

5. McClain KM, Morris DM, Hills SC, Busses $\sqcup$ (1994) The effect of initial spacing on growth and crown development for planted northern conifers: 37 year results. For Chron 70:174-182

6. Yang KC, Hazenberg G (1994) Impact of spacing on tracheid length, relative density, and growth rate of juvenile wood and mature wood in Picea mariana. Can J For Res 24(5):996-1007

7. Yang KC, Hazenberg G (1992) Impact of spacing on sapwood and heartwood in Picea mariana \& Picea glauca. Wood Fiber Sci 24(3):330-336 
8. Yang KC (1994) Impact of spacing on width and basal area of juvenile wood in Picea mariana \& Picea glauca. Wood Fiber Sci 26(4):479-488

9. Zhang SY, Chauret G (2001) Impact of initial spacing on wood characteristics, product quality and value recovery in black spruce (Picea mariana). Res Rep No 1944, Forintek Canada Corp, Quebec City

10. Zhang SY, Koubaa A (2008) Softwoods of eastern Canada: silvics, wood characteristics, processing and end uses. FPInnovations Special Publication, SP-526E, Quebec City, p 330

11. Harris JM, Meylan BA (1965) The influence of microfibril angle on longitudinal and tangential shrinkage in Pinus Radiata. Holzforschung 19:144-153

12. Boyd DJ (1974) Anisotropic shrinkage of wood: identification of the dominant determinants. Mokuzai Gakkaishi 20(10):473-482

13. Cave ID (1972) A theory of the shrinkage of wood. Wood Sci Technol 6:284-292

14. Panshin AJ, De Zeeuw CE (1980) Textbook of wood technology, 4th edn McGraw-Hill Series in Forest Resources, New York, p p722

15. Meylan BA (1968) Cause of high longitudinal shrinkage in wood. For Prod J 18:75-78

16. Voorhies G, Groman WA (1982) Longitudinal shrinkage and occurrence of various fibril angles in juvenile wood of young growth ponderosa pine. For Note No 16. Northern Ariz Univ, Flagstaff

17. Rowe, JS (1972) Forest regions of Canada. Can For Serv, Pub No 1330, Ottawa. p 172

18. Thrower JS (1986) Estimating site quality from early height growth of white spruce and red pine plantations in the Thunder Bay Area. M.Sc.F Thesis, School of Forestry, Lakehead Univ, Thunder Bay

19. Zhang SY, Chauret G, Ren HQ, Desjardins R (2002) Impact of initial spacing on plantation black spruce lumber grade yield, bending properties, and MSR yield. Wood Fiber Sci 34(3):460-475
20. Zhang SY, Zhong Y (1992) Structure-properties relationship of wood in East-Liaoning Oak. Wood Sci Technol 26:139-149

21. Koubaa A, Isabel N, Zhang SY, Beaulieu J (2005) Transition from juvenile to mature wood in black spruce (Picea mariana (Mill) B.S.P). Wood Fiber Sci 37(3):445-455

22. Alteyrac J, Cloutier A, Zhang SY (2006) Chacterization of juvenile wood to mature wood transition age in black spruce ((Picea mariana (Mill) B.S.P) at different stand densities and sampling heights. Wood Fiber Sci 40(2):124-138

23. Koshy MP, Lester DT (1997) Wood shrinkage and tree growth in coastal Douglas-fir: implications of selection. Can J For Res 27(1):135-138

24. Zhang SY, Nepveu G, Owoundi RE (1994) Intratree and intertree variation in selected wood quality characteristics of European oak (Quercus petraea and Quercus robur). Can J For Res 24(9):1818-1823

25. Saranpaa P (1992) Basic density, longitudinal shrinkage and tracheid length of juvenile wood of Picea abies (L.) Karst. Scan J For Res 9:69-74

26. Zobel BJ, Sprague JR (1998) Juvenile wood in forest trees. Springer-Verlag Series in Wood Science, Berlin, p p304

27. Cown DJ, McConchie DL (1983) Radiata pine wood properties survey (1977-1982). New-Zealand Forest Service, FRI Bulletin No 50

\section{Publisher's Note}

Springer Nature remains neutral with regard to jurisdictional claims in published maps and institutional affiliations.

\section{Submit your manuscript to a SpringerOpen ${ }^{\circ}$ journal and benefit from:}

- Convenient online submission

- Rigorous peer review

- Open access: articles freely available online

- High visibility within the field

- Retaining the copyright to your article

Submit your next manuscript at $\boldsymbol{\nabla}$ springeropen.com 